\title{
Activity of Acid Phosphatases in Ectomycorrhizal Fungi
}

\author{
Francilina Araujo Costa ${ }^{1}$, Joselita Cardoso de Souza ${ }^{2}$, Josimara Nolasco Rondon ${ }^{3}$ \\ $\&$ Maria Catarina Megumi Kasuya ${ }^{4}$ \\ ${ }^{1}$ Departamento de Agronomia, Universidade Católica Dom Bosco, Mato Grosso do Sul, Brasil \\ ${ }^{2}$ Departamento de Tecnologia e Ciencias Sociais, Universidade do Estado da Bahia, Bahia, Brasil \\ ${ }^{3}$ Programa de Pós Graduação em Ciencias Ambientais e Sustentabilidade Agropecuária, Universidade Católica \\ Dom Bosco, Mato Grosso do Sul, Brasil \\ ${ }^{4}$ Departamento de Microbiologia, Universidade Federal de Viçosa, Minas Gerais, Brasil \\ Correspondence: Francilina Araujo Costa, Universidade Católica Dom Bosco, Mato Grosso do Sul, Brasil. \\ E-mail: fcosta@ucdb.br
}

Received: December 17, 2015 Accepted: January 30, 2016 Online Published: February 15, 2016

doi:10.5539/jas.v8n3p78 URL: http://dx.doi.org/10.5539/jas.v8n3p78

\begin{abstract}
The colonization of plant roots by mycorrhizal fungi, generally increases P content in the host plant when in soils with low levels of P. The objective of this work was to evaluate the activity of acid phosphatases in two isolates of Pisolithus microcarpus, grown in different sources and concentrations of phosphate and to characterize the phosphatase isoenzymes produced by isolates. Both isolates were grown on Melin-Norkrans modified (MNM) medium enriched with organic (Po) or inorganic (Pi) sources of phosphorus, at five different concentrations, in order to study the activity of mycelial surface acid phosphatases during incubation for up to $96 \mathrm{~h}$. Activity of acid phosphatases increased when the fungi were grown without or at low concentrations of Pi. Intraspecific differences were observed between the isolates with regard to acid phosphatase production. A greater decrease in phosphatase activity was observed when incubation time was increased than when Pi concentration was increased. At an incubation time of $96 \mathrm{~h}$, activity of acid phosphatases in isolate $90 \mathrm{~A}$ increased with increasing Po concentration, while for isolate RV82 remained constant over the different incubation periods and Po concentrations tested. When grown in media without $\mathrm{Pi}$, an additional band appeared in the isoenzyme pattern of RV82, while isoenzyme production was not altered in isolate 90A when grown in media without Pi or with 2 $\mathrm{mM}$ Pi, showing differences in their isoenzyme patterns. Isolate 90A possesses a potential competitive advantage when utilized in mycorrhizal association with Eucalyptus because of its ability to utilize Po.
\end{abstract}

Keywords: in vitro acid phosphatases, isoenzymes, Pisolithus microcarpus, organic phosphate, inorganic phosphate, phosphorous nutrition

\section{Introduction}

The crop production in the tropics is often limited by low levels of some nutrients in in the soil. Among them, phosphorus (P) is perhaps the most limiting to plant growth, given its high stability and low solubility (Kamprath, 1977; Reed et al., 2011). The available P is closely related to the physicochemical characteristics of the soil. Mycorrhiza is a symbiotic association between some soil fungi and the roots of higher plants that are able to improve their nutrition, growth and disease tolerance (Mukerji et al., 2000; Smith \& Read, 2008). Root colonization by mycorrhizal fungi and subsequent formation of mycorrhizae generally results in an increase in phosphorous content of the host plant in soils with low concentrations of this element (Jakobsen, 1995; Moreira \& Siqueira, 2006; Siqueira et al., 2010). Different mechanisms have been proposed to explain the acquisition of phosphorus by mycorrhizal plants (Bowen, 1973; Johnston et al., 2014). Mycorrhizal fungal hyphae contribute to plant phosphorous nutrition by increasing the surface area of the root system thus permitting the exploration of a greater total soil volume (Sawyer et al., 2003; Glowa et al., 2003; Parniske, 2008) as well as by producing surface or extracellular acid phosphatases (Wang et al., 2006; Huang et al., 2009; Wu et al., 2011; Bechem, 2013).

The acid phosphatase (EC 3.1.3.2) has been studied because of its importance in organic P mineralization (Tabatabai, 1994, Olander \& Vitousek, 2000). These enzymes catalyze the hydrolysis of organophosphates to inorganic phosphates which can then be readily absorbed by plants (Tabaldi et al., 2007; Khade et al., 2010; Li et 
al., 2011). Among the organic compounds, it can be mentioned p-nitrophenyl phosphate, glucose 6-phosphate, beta-glycerophosphate, inositol hexaphosphate, inositol triphosphate (Bartlett \& Lewis, 1973). The organic fraction of soil phosphorous constitutes a considerable reservoir of phosphorous for plants and can vary from 20 to $80 \%$ of the total soil phosphorous content, of which phytic acid (inositol hexaphosphate) comprises a major component (Richardson, 1999), being a particularly important source of this element in forest soils. Since plants do not assimilate organic phosphorous, this fraction must be converted to soluble inorganic phosphate (Griffiths \& Caldwell, 1992; Reed et al., 2011).

Acid phosphatases predominate in acid soils (Tran et al., 2010) and fungi generally present higher activities of these phosphatases (van Aarle \& Plassard, 2010). Intra and interspecific differences in phosphatase activities have been observed in ectomycorrhizal fungi (Sawyer et al., 2003). Factors such as pH (Alvarez et al., 2005), fungal growth rate and temperature (Chethan Kumar et al., 2008), mycelial age (Nygren \& Rosling, 2009), water stress (Wu et al., 2011) mycorrhizal colonization (Stancheva et al., 2008; Wu et al., 2011) and phosphorous source and concentration (Nygren \& Rosling, 2009; van Aarle \& Plassard, 2010; Tran et al., 2010; Bechem, 2013) all influence acid phosphatase activity.

Among these factors, inorganic phosphorous is probably the most important in vivo repression of phosphatase synthesis (van Aarle \& Plassard, 2010; Tran et al., 2010; Li et al., 2011). Deficiency or absence of phosphate in the culture medium leads to a significant increase in activity of acid phosphatases in ectomycorrhizal fungi (Tibbett et al., 1998; Tran et al., 2010; Bechem, 2013). This increase in activity results from the normal secretion of surface phosphatases and liberation of extracellular phosphatases (Alvarez et al., 2005; Tran et al., 2010) leading to a more efficient utilization of different forms of organic phosphorous (Wang et al., 2006; Khade et al., 2010), thereby contributing to the nutrition of infected plants (Stancheva et al., 2008; Wu et al., 2011; Li et al., 2011).

The study of factors that interfere in the synthesis and activity of these enzymes in ectomycorrhizal fungi may contribute to the establishment of criteria for the selection of ectomycorrhizal fungi for the use in controlled programs of introduction of mycorrhizal associations in forest species, such as Eucalyptus and Pinus, species important species used for reforestation in Brazil typically, which has occurred in wide areas, with soil phosphate deficiency. Pisolithus microcarpus is the most frequently fungus found in association with eucalypt in Brazil, so to analyze the factors that interfere with the activity of these enzymes are important. Thus, the objective of this work was to evaluate the activity of acid phosphatases in two isolates of Pisolithus microcarpus, grown in different sources and concentrations of phosphate as well as to characterize the phosphatase isoenzymes produced by the two isolates.

\section{Methods}

\subsection{Ectomycorrhizal Fungi Culture}

The ectomycorrhizal fungi used were Pisolithus microcarpus, isolates 90A and RV82 belonging to the Laboratory Mycorrhizal Association, of the Department of Microbiology/Institute for Biotechnology Applied to Agriculture and Livestock (BIOAGRO), of the Universidade Federal de Viçosa. The isolates came from basidiocarps collected under Eucalyptus spp. plantations.

The culture media used in the experiments was modified MNM (Marx, 1969) (MS1), with the following composition: $0.68 \mathrm{mM} \mathrm{CaCl} 2 ; 0.43 \mathrm{mM} \mathrm{NaCl} ; 0.61 \mathrm{mM} \mathrm{MgSO}$; $1.7 \mathrm{mM} \mathrm{KCl} ; 2.27 \mathrm{mM} \mathrm{NH}_{4} \mathrm{Cl} ; 2.0 \mathrm{mM}$ $\mathrm{KH}_{2} \mathrm{PO}_{4} ; 0.04 \mathrm{mM} \mathrm{FeCl}_{3} ; 100 \mu \mathrm{g} \mathrm{L}{ }^{-1}$ thiamine; $10 \mathrm{~g} \mathrm{~L}^{-1}$ glucose; $15 \mathrm{~g}$ agar-agar; completed in $1000 \mathrm{~mL}$ distilled water, $\mathrm{pH}$ 5.5. Liquid medium with (ML1) or without (ML0) phosphorous (P) was also used. The medium ML1 and ML0 has the same composition of MS1, with the following modifications thiamine $\left(25 \mu \mathrm{g} \mathrm{L}^{-1}\right)$, glucose $(10 \mathrm{~g}$ $\left.\mathrm{L}^{-1}\right), \mathrm{KCl}(3.7 \mathrm{mM}$ ), lower concentration of phosphorous (2 mM P) (ML1) and without phosphorous (ML0).

\subsection{Determination of Stabilization Time of Mycelial P Content}

Mycelia of isolates 90A and RV82 were grown on $90 \mathrm{~mm}$ diameter Petri dishes containing $20 \mathrm{~mL}$ of MS1 medium. After 15 days of growth, 3 disks, of approximately $9 \mathrm{~mm}$ in diameter, containing fungal mycelia were transferred to $125 \mathrm{~mL}$ Erlenmeyer with $50 \mathrm{~mL}$ of ML0 medium. The flasks were incubated at $28{ }^{\circ} \mathrm{C}$, without shaking, in the dark. After 7, 11, 13, 15, 17, 19 and 21 days of growth, the mycelia of four replicates were collected individually, by screening, washed with distilled water, transferred to pre-weighed aluminum foil recipients, and dried at $110^{\circ} \mathrm{C}$ for $48 \mathrm{~h}$. The dried mycelia were digested in a nitric perchloric acid mixture for 30 to $40 \mathrm{~min}$ (Johnson \& Eurich, 1959). P content was determined colorimetrically by the vitamin C method (Braga \& Defelipo, 1974). 


\subsection{Activity of Acid Phosphatases in the Intact Mycelium}

Fungal mycelia were grown on Petri dishes containing MS1 medium at $28{ }^{\circ} \mathrm{C}$ for 15 days to determine activity of acid phosphatases. After this period, three disks containing mycelia were removed from the edges of the colonies and transferred to $125 \mathrm{~mL}$ Erlenmeyer flasks containing $50 \mathrm{~mL}$ of ML0 medium.

The inoculated flasks were incubated at $28{ }^{\circ} \mathrm{C}$, in the dark, without shaking, for 20 days. After this period, the mycelia were transferred aseptically to fresh $125 \mathrm{~mL}$ Erlenmeyer flasks containing $50 \mathrm{~mL}$ of ML0 medium enriched with organic phosphate (inositol sodium hexaphosphate) or inorganic phosphate $\left(\mathrm{KH}_{2} \mathrm{PO}_{4}\right)$, at concentrations corresponding to $0 ; 20 ; 40 ; 80$ and $160 \mu \mathrm{M}$ of phosphorus. The flasks were incubated at $28{ }^{\circ} \mathrm{C}$, in the dark, without shaking, for periods of 6, 24 and $96 \mathrm{~h}$. Determinations of activity of acid phosphatases were performed at the end of each incubation period, according to the methodology described by Tabatabai and Bremner (1969).

Analyses of variance were performed on the phosphatase activity data from each incubation period at each concentrations of P. Controls were run for each combination of fungus and source of organic or inorganic phosphorous in the culture medium. A randomized split plot design with 4 repetitions for isolate $90 \mathrm{~A}$ and five repetitions isolate RV82 was used. First order regression curves were adjusted to the data, with incubation time and phosphate concentration as independent variables and phosphatase activity as dependent variable.

\subsection{Detection of Acid Phosphatase Isoenzymes}

Fungal isolates 90A and RV82 were grown in Petri dishes containing MS1 medium at $28^{\circ} \mathrm{C}$ for 15 days to detect acid phosphatase isoenzymes. After this period, 3 disks of approximately $9 \mathrm{~mm}$ in diameter were removed from the edges of the colonies and transferred to $125 \mathrm{~mL}$ Erlenmeyer flasks containing $50 \mathrm{~mL}$ of ML0 or ML1 medium. The flasks were incubated at $28^{\circ} \mathrm{C}$, in the dark, without shaking, for 7 days. After this period of incubation mycelia were collected, washed, weighed and macerated after addition of $1 \mathrm{~mL}$ of extraction solution (Alfenas et al., 1991) and trace quantities of polyvinylpolypirrolidone, to remove phenolic compounds and increase enzyme stability. The macerated material was covered with absorbent paper followed by $1.2 \times 0.5 \mathrm{~cm}$ strips of Whatman 3MM chromatographic paper to absorb the extract. The strips were applied to $12 \%$ hydrolysed starch $\left(\right.$ Sigma $\left.^{\circledR}\right)$ electrophoresis gel (Alfenas et al., 1991). The buffer system in the electrode compartments consisted of boric acid $(0.188 \mathrm{M})$ and lithium hydroxide $(0.038 \mathrm{M})$ at $\mathrm{pH} 8.3$. The gel was prepared with Tris $(0.045 \mathrm{M})$ and citric acid $(0.007 \mathrm{M})$ in $100 \mathrm{~mL}$ buffer and completed to a final volume of $1000 \mathrm{~mL}$ with distilled water. The acid phosphatase isoenzymes were detected by staining (Soltis et al., 1983). After development, the gel was fixed in a $10 \%$ glycerin solution for $12 \mathrm{~h}$ at $4{ }^{\circ} \mathrm{C}$. Gels were dehydrated by the bastidor method (Alfenas et al., 1991).

\section{Results}

\subsection{Determination of Stabilization Time of Mycelial Phosphorous Content}

The mycelial phosphorus content of P. microcarpus isolates 90A and RV82 grown for 15 days in MS1 medium containing $2 \mathrm{mM}$ phosphate decreased about 4-fold when the same mycelia were transferred and grown in ML0 medium without phosphate for 20 days (Figure 1).

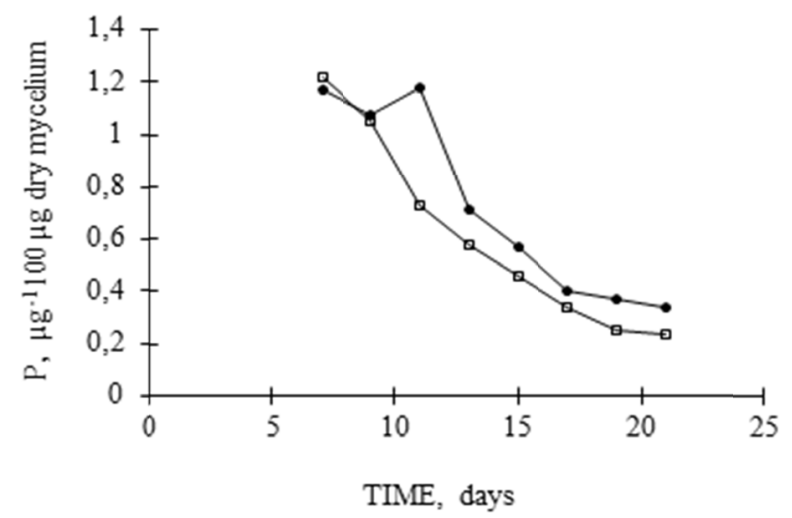

Figure 1. Phosphorous concentration ( $\mu \mathrm{g}^{-1} 100 \mu \mathrm{g}$ dry mycelium), in the different period of time (days) of two isolate of Pisolithus microcarpus $(\bullet-$ P. microcarpus $90 \mathrm{~A}, \square-$ P. microcarpus RV82) grown in modified liquid MNM medium, without phosphorous at $28^{\circ} \mathrm{C}$ 
Stabilization of mycelial phosphate content in ML0 medium occurred between days 17 and 21 of growth. Based on these results, mycelia were harvested after 20 days for acid phospatase activity experiments. This procedure was necessary to ensure depletion of the mycelial phosphate reserves and avoid interference of the phosphate contained in the fungal disks and mycelial inoculates with the activity of the acid phosphatases at the different levels of phosphate and incubation times studied.

\subsection{Determination of Activity of Acid Phosphatases in the Intact Mycelium}

P. microcarpus isolate 90A did not present significantly different activity of acid phosphatases when grown at different concentrations of inorganic phosphate. However, at the highest concentration of inorganic phosphate $(160 \mu \mathrm{M})$, an average estimated decrease in phosphatase activity of $43.9 \mu \mathrm{mol}$ of $\mathrm{p}$-nitrophenyl phosphate (pNPP) $\mathrm{g}^{-1}$ dry mycelium ${ }^{-1}$ hour $^{-1}$ was observed after a one hour incubation period as compared to the treatment without phosphate (Table 1).

Table 1. Estimated regression equations for activities of acid phosphatases (Y) in Pisolithus microcarpus isolates $90 \mathrm{~A}$ and RV82, as a function of incubation period of time in hours $(\mathrm{H})$, and organic (inositol sodium hexaphosphate) or inorganic (potassium phosphate, monobasic) phosphate concentration (P)

\begin{tabular}{llllll}
\hline Isolate & P Source & Equation & ${ }^{* C V P}$ & ${ }^{* * C V T}$ & $\mathrm{r}^{2}$ \\
\hline 90A & Organic P & $\mathrm{Y}=426.2850+0.9848 \mathrm{H}+0.3172 \mathrm{P}$ & $10.93 \%$ & $13.27 \%$ & 0.8646 \\
& Inorganic P & $\mathrm{Y}=486.6900-0.9326 \mathrm{H}-0.2741 \mathrm{P}$ & $14.93 \%$ & $12.07 \%$ & 0.7664 \\
\hdashline RV82 & Inorganic P & $\mathrm{Y}=302.1120-0.3386 \mathrm{H}-0.2157 \mathrm{P}$ & $11.60 \%$ & $13.79 \%$ & 0.5031 \\
\hline
\end{tabular}

Note. * Coefficient of variation of phosphate concentration; ** Conefficient of variation of incubation time.

In P. microcarpus isolate RV82 the greatest estimated reductions were $301.8 \mu \mathrm{mol} \mathrm{pNPP}^{-1} \mathrm{dry}^{\mathrm{mycelium}}{ }^{-1}$ hour $^{-1}$, in the treatment without phosphorous in the culture medium, and $267.3 \mu \mathrm{mol} \mathrm{pNPP} \mathrm{g} \mathrm{p} \mathrm{dry} \mathrm{mycelium} \mathrm{h}^{-1}$, in the treatment containing $160 \mu \mathrm{M}$ inorganic phosphorous, after a one hour incubation period (Table 1). Inorganic phosphate is possibly the most influential factor in the repression of acid phosphatase synthesis in $P$. microcarpus isolate RV82.

Intraspecific differences in acid phosphatases were demonstrated by the regression equations obtained for the activities of mycelial acid phosphatases of $P$. microcarpus isolates 90A and RV82 grown in ML0 medium containing different concentrations of organic or inorganic phosphate (Table 1).

Incubation time in MNM medium caused greater decreases in acid phosphatase activity values than did the concentration of inorganic phosphate in the growth medium. For each day of $P$. microcarpus isolate 90A growth, an average estimated decrease in activity of $22.4 \mu \mathrm{mol} \mathrm{pNPP} \mathrm{g}^{-1}$ dry mycelium $\mathrm{h}^{-1}$ was observed (Table 1). Similarly, in P. microcarpus RV82, the estimated average daily reduction in activity was $8.1 \mu \mathrm{mol} \mathrm{pNPP}^{-1} \mathrm{dry}$ mycelium $\mathrm{h}^{-1}$ (Table 1).

The organic phosphorous source in the culture medium only influenced the acid phosphatase activity significantly in P. microcarpus isolate 90A. The activity of the phophatases in isolate 90A increased linearly with the increase in organic phosphate in the culture medium. In the absence of phosphate, the average estimated activity value after a one hour period was $427.3 \mu \mathrm{mol} \mathrm{pNPP} \mathrm{g}^{-1}$ dry mycelium $\mathrm{h}^{-1}$, whereas the average of the estimated activity values in the medium containing $160 \mu \mathrm{M}$ phosphorous was $478 \mu \mathrm{mol} \mathrm{pNPP}^{-1} \mathrm{dry}_{\text {mycelium }}$ $\mathrm{h}^{-1}$ (Table 1). Differently from what was observed for P. microcarpus 90A, in P. microcarpus isolate RV82 activity of acid phosphatases did not change significantly in the presence of organic phosphate, over the incubation periods and at the concentrations evaluated, varying from 242.8 to $279.9 \mu \mathrm{mol} \mathrm{pNPP}^{-1} \mathrm{dry}$ mycelium $\mathrm{h}^{-1}$.

In culture media containing an organic phosphate source, the incubation period showed a significant effect on acid phosphatase activity of isolate 90A. Phosphatase activity in isolate RV82 was not altered during the periods evaluated. For isolate 90A, daily estimated increases in activity corresponded to $23.6 \mu \mathrm{mol} \mathrm{pNPP}^{-1}$ dry mycelium $\mathrm{h}^{-1}$ (Table 1). The average estimated acid phosphatase activity after $6 \mathrm{~h}$ of incubation at a concentration of $160 \mu \mathrm{M}$ phosphate was $482.9 \mu \mathrm{mol} \mathrm{pNPP}^{-1}$ dry mycelium $\mathrm{h}^{-1}$ and increased over time, reaching a value of $571.6 \mu \mathrm{mol} \mathrm{pNPP}^{-1}$ dry mycelium $\mathrm{h}^{-1}$ at $96 \mathrm{~h}$ (Table 1).

\subsection{Detection of Acid Phosphatase Isoenzymes in Ectomycorrhizal Fungi}

The isoenzymes pattern of the fungal isolates was determined by the number and migration distance of the bands 
developed after electrophoresis of the enzyme mixture. The two isolates presented different isoenzymes patterns (Figures 2 and 3).

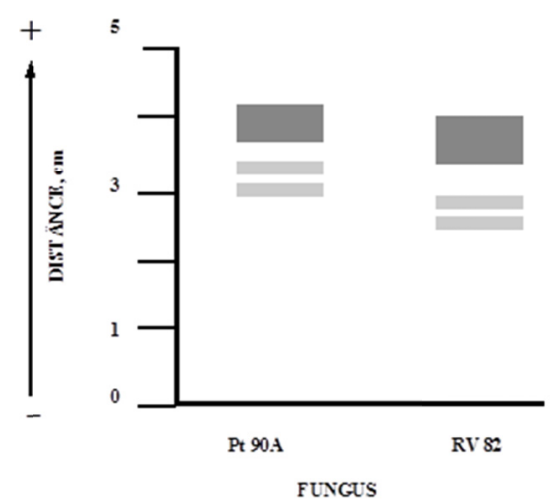

Figure 2. Acid phosphatase band patterns after electrophoresis in $12 \%$ starch gel of Pisolithus microcarpus isolates grown in modified liquid MNM with $2 \mathrm{mM}$ inorganic phosphate for 7 days. (P. microcarpus isolate 90A: Pt90A; P. microcarpus isolate RV82: RV82)

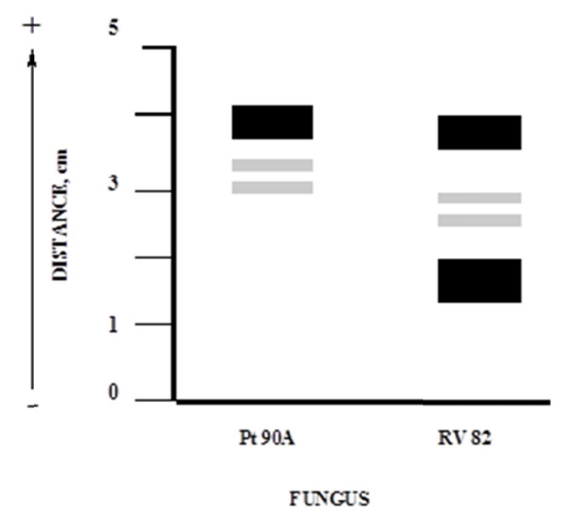

Figure 3. Acid phosphatase band patterns after electrophoresis in $12 \%$ starch gel of Pisolithus microcarpus isolates grown in modified liquid MNM medium without phosphate for 7 days. (P. microcarpus isolate 90A: Pt90A; P. microcarpus isolate RV82: RV82)

When grown in the absence of phosphorous, one additional band appeared in the isoenzyme pattern of isolate RV82, while the production of isoenzymes was not altered in isolate $90 \mathrm{~A}$ when grown in medium containing 2 $\mathrm{mM}$ inorganic phosphate or in medium without phosphate (Figures 2 and 3). On the other hand, both the isoenzyme pattern and acid phosphatase activity of P. microcarpus isolate RV82 were altered when phosphorous was absent from the growth medium.

\section{Discussion}

The content of phosphate in the mycelium and the source of phosphate in the fungal growth medium affect the phosphatase activity (Nygren \& Rosling, 2009; van Aarle \& Plassard, 2010; Tran et al., 2010; Bechem, 2013).

Similar results of activity of acid phosphatases in the mycelium have been found for other species and isolates of ectomycorrhizal fungi. The inverse relationship between acid phosphatase activity and inorganic phosphate concentration in the culture medium has also been demonstrated in other ectomycorrhizal fungi, such as Cenococcum geophilum, Entoloma sericeum, Scleroderma citrinum, Hebeloma cylindrosporum, H. edurum, Suillus granulatus (Calleja \& D'auzac, 1983; Kroehler et al., 1988; Leprince \& Quiquampoix, 1996; van Aarle \& Plassard, 2010; Bechem, 2013).

Deficiency or absence of inorganic phosphate in the culture medium can lead to a significant increase in activity of acid phosphatases in ectomycorrhizal fungi (Ascencio, 1994; Taniguchi et al., 2008; Tran et al., 2010; Bechem, 2013). The increase in activity of acid phosphatases has been attributed to greater synthesis of these enzymes 
(Alvarez et al., 2006; Tran et al., 2010), which can result in more effective utilization of different forms of organic phosphate. The extramatrical mycelium of ectomycorrhizal fungi as mentioned by Alvarez et al. (2006) play a specific role in the P uptake. They could also be involved in recapturing of excreted plant or fungal compounds. These phosphatases could possibly break down and recycle the phospholipids from old hyphae (Nygren \& Rosling, 2009).

Intra- and interspecific differences in acid phosphatase activities of ectomycorrhizal fungi have been reported in other studies (Alvarez et al., 2006; Taniguchi et al., 2008; Bechem, 2013). Recognition of this phenomenon may lead to use of acid phosphatase activity values as a criterion for selection of ectomycorrhizal fungi for use as inoculum in mycorrhizal association programs. However, the activity of these phosphatases under field conditions should be evaluated prior to adopting such a criterion.

The activity of acid phosphatase in Pinus pinaster inoculated with Hebeloma cylindrosporum correlates with the form and content of phosphorus. Mycorrhizal plants showed higher acid phosphatase activity compared to non-mycorrhizal plants and mycorrhizal roots showed high acid phosphatase activity when grown in soils with low P levels when compared to soils with high and medium levels of P (van Aarle \& Plassard, 2010). According to these authors, this suggests that the acid phosphatase activity associated with the extrametrical mycelium was stimulated by the absence of easily available phosphate, and was not, as might have been expected, much influenced by the form in which P was bound in the soil. Like Nygren and Rosling (2009), we did not observe a significantly higher acid phosphatase activity associated with the extramatrical mycelium when exposed to organic soil P. It might thus be that available phosphate is a more important factor to the acid phosphatase activity than the form in which $\mathrm{P}$ was bound in the soil. However, acid phosphatase activities were greater in the organic layer than the mineral soil, especially under evergreen forests (Redel et al., 2008).

Ours results suggest that an inverse relationship exists between acid phosphatase activity and incubation time. A sharp reduction in extracellular acid phosphatase activity was also observed in two isolates of C. geophilum, in medium with $2 \mu \mathrm{M}$ or $50 \mu \mathrm{M}$ inorganic phosphate during incubation times of 12, 24, 36 and 48 hours (Kroehler et al., 1988).

Ectomycorrhizal fungi that increase their acid phosphatase activity in the presence of organic phosphate may have a competitive advantage in obtaining phosphorous in soils where organic phosphorus forms predominate, such as is the case for forest soils, and converting these to forms readily assimilated by plants. Acid phosphatases may limit the competitive action of fungi in locations where organophosphates are the main phosphorus source.

The ectomycorrhizal fungi Pisolithus spp. are distributed worldwide, forming ectomicorrhizae with various hosts. This species is tolerant to high temperature, acid and low humidity environments (Marx, 1982). P. microcarpus isolate 90A presented higher acid phosphatase activity than isolate RV82 and was able to utilize organic phosphate sources. Thus, it is suggested that this isolate possesses a potential competitive advantages when used as a Eucalyptus inoculate.

Differences in isoenzymes patterns within and among species have been documented for various ectomycorrhizal fungi. The lack of phosphate in the medium induces the expression of new acid phosphatases. In Hebeloma edurum and Suillus granulatus, the appearance of new bands after growth of the fungi without inorganic phosphate in the culture medium, as compared to growth in medium containing phosphate, was also observed (Calleja \& D'Auzac, 1983). The isoenzyme pattern of P. tinctorius was not altered when the fungus was grown in medium either with or no phosphate (Berjaud \& D'Auzac, 1986).

The increase in phosphatase activity has been attributed to synthesis of enzymes of the same type or to the activation of preexisting acid phosphatases (Wasaki et al., 2009; Tran et al., 2010; Li et al., 2011).

Up-regulation of root secreted acid phosphatase activity is common for plants in response to P deficiency. A number of studies have reported that secretion and expression of acid phosphatase are enhanced under $\mathrm{P}$ deficient conditions (Playsted et al., 2006; Wasaki et al., 2009). When evaluating roots of Medicago falcata a seedlings grown in $\mathrm{P}$ sufficient $\left(500 \mu \mathrm{M} \mathrm{H}_{2} \mathrm{PO}_{4}\right)$ and P-deficient $\left(5 \mu \mathrm{M} \mathrm{H}_{2} \mathrm{PO}_{4}\right)$ solution there was a marked increase in activity of root acid phosphatase (APase) and expression of gene encoding APase (MfPAPI) under P deficient conditions (Li et al., 2010).

For the isolate RV82 one additional band appeared in the isoenzyme pattern when grown in the absence of phosphorous. Similarly, the Arabidopsis genome encodes 29 different purple acid phosphatases whose expression is influenced by various developmental and environmental factors. Pi starvation induces de novo synthesis of several extra and intracellular Arabidopsis purple acid phosphatase isozymes, AtPAP12 and AtPAP26 appear to be the principal root-secreted acid phosphatases that scavenge Pi from extracellular Pi-esters, 
whereas the dual-targeted AtPAP26 is the predominant intracellular acid phosphatase that functions in vacuolar Pi recycling by Pi-starved Arabidopsis (Tran et al., 2010).

Quantitative real-time PCR in soybean, Glycine max, was employed to analyze the expression patterns of Purple acid phosphatases (PAPs) genes in response to P deficiency and symbiosis. Key results in total, 35 PAP genes were identified from soybean genomes. The expression of 23 GmPAPs was induced or enhanced by Pi starvation in different tissues. Among them, nine GmPAP genes were highly expressed in the Pi-deprived nodules, whereas only two GmPAP genes showed significantly increased expression in the arbuscular mycorrhizal roots under low-P conditions. Conclusions most GmPAP genes are probably involved in $\mathrm{P}$ acquisition and recycling in plants (Li et al., 2011; Zhang et al., 2011).

The increase in synthesis or activity of acid phosphatases may be due to the synthesis of new inducible isoenzymes localized in the cell wall or the external face of the plasma membrane (Pasqualini et al., 1992), or to the activation of preexisting molecules (Berjaud \& D'Auzac, 1986; Playsted et al., 2006; Wasaki et al., 2009; Tran et al., 2010; Li et al., 2011). It is suggested, therefore, that the increasing in acid phosphatase activity in $P$. microcarpus RV82, when grown in medium without phosphate or with low concentrations of inorganic phosphate may be partly due to the production of new types of isoenzymes. In the other hand, the isolate of $P$. microcarpus $90 \mathrm{~A}$ possesses a potential competitive advantage when in mycorrhizal association with Eucalyptus because of its ability to utilize Po.

\section{References}

Alfenas, A. C., Peters, I., Brune, W., \& Passador, G. C. (1991). Eletroforese de proteinas e isoenzimas de fungos e essências florestais (p. 242). Viçosa, MG: Universidade Federal de Viçosa.

Alvarez, M., Gieseke, A., Godoy, R., \& Härtel, S. (2006). Surface-bound phosphatase activity in ectomycorrhizal fungi: A comparative study between a colorimetric and a microscope-based method. Biology and Fertility of Soils, 42, 561-568. http://dx.doi.org/10.1007/s00572-012-0461-z

Alvarez, M., Godoy, R., Heyser, W., \& Hartel, S. (2005). Anatomical-physiological determination of surface bound phosphatase activity in ectomycorrhizae of Nothofagus oblique. Soil Biology \& Biochemistry, 37, 125-132. http://dx.doi.org/10.1100/2012/250805

Antibus, R. K., Sinsabaugh, R. L., \& Linkins, A. E. (1992). Phosphatase activities and phosphorus uptake from inositol phosphate by ectomycorrhizal fungi. Canadian Journal of Botany, 70(4), 794-801. http://dx.doi.org/10.1139/b92-101

Ascencio, J. (1994). Acid phosphatase as a diagnostic tool. Communications in Soil Science and Plant Analyses, 25, 1553-1564. http://dx.doi.org/10.1080/00103629409369135

Bartlett, E. M., \& Lewis, D. H. (1973). Surface phosphatases activity of mycorrhizal roots of beech. Soil Biology Biochemistry, 5, 249-257. http://dx.doi.org/10.1016/0038-0717(73)90008-4

Bechem, E. E. T. (2013). Acid phosphatase activity of the pantropical fungus Scleroderma sinnamariense in pure culture. African Journal of Microbiology Research, 7, 2835-2842. http://dx.doi.org/10.5897/AJMR12.251

Berjaud, C., \& D'auzac, J. (1986). Isolement et caractérisation des phosphatases d'un champignon ectomycorhizogêne typique: Phisolithus tinctorius, effects de la carence en phosphate. Physiologie Vegetale, 24, 163-172.

Bowen, G. D. (1973). Mineral nutrition of ectomycorrhizae. In G. D. Marks \& T. T. Koslowskil (Eds.), Ectomycirrhizae: Their ecology and physiology (pp. 151-205). http://dx.doi.org/10.1016/b978-0-12-472850-9.50011-6

Braga, J. M., \& Defelipo, B. V. (1974). Determinação espectrofotométrica de fósforo em extratos de solo e material vegetal. Revista Ceres, 21, 73-75. http://dx.doi.org/AG19750006241

Calleja, M., \& D'auzac, J. (1983). Activités phosphatases et carence phasophatée chez des champignons supérieurs. Canadian Journal of Botany, 61, 79-86. http://dx.doi.org/10.1139/b83-007

Chethan Kumar, K. V., Chandrashekar, K. R., \& Lakshmipathy, R. (2008). Variation in arbuscular mycorrhizal fungi and phosphatase activity associated with Sida cardifolia in Karnataka. World Journal of Agricultural Science, 4, 770-774.

Glowa, K. R., Arocena, J. M., \& Massicotte, H. B. (2003). Extraction of potassium and/or magnesium from selected soil minerals by Piloderma. Geomicrobiology Journal, 20, 99-111. http://dx.doi.org/10.1080/01490450303881 
Griffiths, R. P., \& Caldwell, B. A. (1992). Mycorrhizal mat communities in forest soils. In D. J. Read, D. H. Lewis, A. H. Fitter, \& I. J. Alexander (Eds.), Mycorrhizas in ecosystems. Wallingford: CAB International.

Huang, H., Zhang, S., Wu, N., Luo, L., \& Christie, P. (2009). Influence of Glomus etunicatum/Zea mays mycorrhiza on atrazine degradation, soil phosphatase and dehydrogenase activities, and soil microbial community structure. Soil Biology \& Biochemistry, $41, \quad 726-734$. http://dx.doi.org/10.1016/j.soilbio.2009.01.009

Jakobsen, I. (1995). Transport of phosphorus and carbon in VA Mycorrhizas. In A. Varma \& B. Hock (Eds.), Mycorrhiza: Structure, function, molecular biology and biotechnology. Berlin: Springer-Verlag. http://dx.doi.org/10.1007/978-3-662-08897-5_14

Johnson, C. M., \& Eurich, A. (1959). Analytical methods for use in plant analysis (Bulletin 766, pp. 32-33). California, USA: University of California.

Johnston, A. E., Poulton, P. R., Fixen, P. E., \& Curtin, D. (2014). Phosphorus: Its efficient use in agriculture. Advances in Agronomy, 123, 177-228. http://dx.doi.org/10.1016/B978-0-12-420225-2.00005-4

Kamprath, E. J. (1977). Phosphorus fixation and availability in highly weathered soil. In M. G. Ferri (Ed.), Simpósio sobre o Cerrado: Bases para Utilização Agropecuária 4 (pp. 333-347). Belo Horizonte. Anais. São Paulo: Universidade de São Paulo.

Khade, S. W., Rodrigues, B. F., \& Sharma, P. K. (2010). Arbuscular mycorrhizal status and root phosphatase activities in vegetative Carica papaya L. varieties. Acta Physiologia e Plantarum, 32, 565-574. http://dx.doi.org/10.1007/s11738-009-0433-X

Kroehler, C. J., Antibus, R. K., \& Linkins, A. E. (1988). The effects of organic and inorganic phosphorus concentration on the acid phosphatase activity of ectomicorrhizal fungi. Canadian Journal of Botany, 66, 750-756. http://dx.doi.org/10.1139/b88-111

Leprince, F., \& Quiquampoix, H. (1996). Extracellular enzyme activity in soil: effect of pH and ionic strength on the interaction with montmorillonite of two acid phosphatases secreted by the ectomycorrhizal fungus Hebeloma cylindrosporum. European Journal of Soil Science, 47, 511-522. http://dx.doi.org/10.1111/j.1365-2389.1996.tb01851.x

Li, C., Gui, S., Yang, T., Walk, T., Wang, X., \& Liao, H. (2011). Identification of soybean purple acid phosphatase genes and their expression responses to phosphorus availability and symbiosis. Annals of Botany, mcr246109(1), 275-85. http://dx.doi.org/br.10.1093/aob/mcr246

Li, Y. S., Gao, Y., Tian, Q. Y., Shib, F. S., Li, L. H., \& Zhang, W. H. (2010). Stimulation of root acid phosphatase by phosphorus deficiency is regulated by ethylene in Medicago falcata. Environmental and Experimental Botany, 71, 114-120. http://dx.doi.org/10.1016/j.envexpbot.2010.11.007

Marx, D. H. (1969). The influence of ectotrofic mycorrhizal fungi on tree resistance of pine roots to pathogenic. I. Antagonism of mycorrhizal fungi to root pathogenic fungi and soil bacteria. Phytopathology, 59, 153-163.

Marx, D. H., Ruehle, J. L., Kenney, D. S., Cordell, C. E., Riffle, J. W., \& Goodwin, O. C. (1982). Commercial vegetative Inoculum of Pisolithus tinctorius and inoculation techniques for development of ectomycorrhizae on container grown tree seedlings. Forest Science, 2, 373-400.

Moreira, F. M. S., \& Siqueira, J. O. (2006). Micorriza. Microbiologia e bioquímica do solo (2nd ed., pp. 543-716). Lavras: Universidade Federal de Lavras.

Mukerji, K. G., Chamola, B. P., \& Singh, J. (2000). Mycorrhizal Biology (p. 336). Khwer Academic/Plenum. Publischers, New York. http://dx.doi.org/10.1007/978-1-4615-4265-0

Nygren, C. M. R., \& Rosling, A. (2009). Localization of phosphomonoesterase activity in ectomycorrhizal fungi grown on different phosphorus sources. Mycorrhiza, 197-204. http://dx.doi.org/10.1007/s00572-008-0223-0

Olander, L. P., \& Vitousek, P. M. (2009). Regulation of soil phosphatase and chitinase activity by N and P availability. Biogeochemistry, 49, 175-191. http://dx.doi.org/10.1023/A:1006316117817

Parniske, M. (2008). Arbuscular mycorrhiza: The mother of plant root endosymbioses. Nature Reviews Microbiology, 6, 763-775. http://dx.doi.org/10.1038/nrmicro1987

Pasqualini, S., Panara, F., \& Antonielli, M. (1992). Acid phosphatase activity in Pinus pinea-tuber albidum ectomycorrhizal association. Canadian Journal of Botany, 70, 1377-1383. 
http://dx.doi.org/10.1139/b92-173

Playsted, C. W. S., Johnston, M. E., Ramage, C. M., Edwards, D. G., Cawthray, G. R., \& Lambers, H. (2006). Functional significance of dauciform roots: Exudation of carboxylates and acid phosphatase under phosphorus deficiency in Caustis blakei (Cyperaceae). New Phytolologist, 170, 491-500. http://dx.doi.org/10.1111/j.1469-8137.2006.01697.x

Redel, Y., Rubio, R., Godoy, R., \& Borie, F. (2008). Phosphorus fractions and phosphatase activity in an Andisol under different forest ecosystems. Geoderma, $216-221$. http://dx.doi.org/10.1016/j.geoderma.2008.03.007

Reed, S. C., Townsend, A. R., Taylor, P. G., \& Cleveland, C. C. (2011). Phosphorus Cycling in Tropical Forests Growing on Highly Weathered Soils. In E. Bünemann, A. Oberson, \& E. Frossard (Eds.), Phosphorus in Action (pp. 339-369). Springer Berlin, Heidelberg. http://dx.doi.org/10.1007/978-3-642-15271-9_14

Richardson, A. E. (1999). Soil microorganisms and phosphorus availability. In C. E. Pankhurst, B. M. Doube, V. V. S. R. Gupts, \& P. R. Grace (Eds.), Soil Biota, Management in Sustainable Farming Systems. CSIRO, Melbourne, Australia.

Sawyer, N. A., Chambers, S. M., \& Cairney, J. W. G. (2003). Utilization of inorganic and organic phosphorus sources by isolates of Amanita muscaria and Amanita species native to temperate eastern Australia. Australian Journal of Botany, 51, 151-158. http://dx.doi.org/10.1071/BT02073

Siqueira, J. O., Souza, F. A., Cardoso, J. B. N., \& Tsai, S. M. (2010). Micorrizas: 30 anos de Pesquisa no Brasil (1st ed.). Lavras: Universidade Federal de Lavras.

Smith, S. E., \& Read, D. J. (2008). Mineral nutrition, toxic element accumulation and water relations of arbuscular mycorrhizal plants. In S. E. Smith, \& D. J. Read (Eds.), Mycorrhizal Symbiosis (pp. 145-18). Academic Press, London. http://dx.doi.org/10.1016/b978-012370526-6.50007-6

Soltis, D. E., Haufler, C. H., Darrow, D. C., \& Gastony, G. J. (1983). Starch ge 1 electrophoresis of ferns: A compilation of grinding buffers, gel and eletrode buffers, and staining schedules. American Fern Journal, 73, 9-27. http://dx.doi.org/10.2307/1546611

Stancheva, I., Geneva, M., Djonova, E., Kaloyanova, N., Sichanova, M., Boychinova, M., \& Georgiev, G. (2008). Response of alfalfa (Medicago sativa L.) growth at low accessible phosphorus source to the dual inoculation with mycorrhizal fungi and nitrogen fixing bacteria. General and Applied Plant Physiology, 34, 319-326.

Tabaldi, L. A., Ruppenthal, R., Cargnelutti, D., Morsch, V. M., Pereira, L. B., \& Schetinger, M. R. C. (2007). Effects of metal elements on acid phosphatase activity in cucumber (Cucumis sativus L.) Seedlings. Environmental and Experimental Botany, 59, 43-48. http://dx.doi.org/10.1016/j.envexpbot.2005.10.009

Tabatabai, M. A., \& Bremner, J. M. (1969) Use of nitrophenyl phosphate for assay of soil phosphatase activity. Soil Biology \& Biochemistry, 1, 301-307. http://dx.doi.org/10.1016/0038-0717(69)90012-1

Taniguchi, T., Kataoka, R., \& Futai, K. (2008). Plant growth and nutrition in pine (Pinus thunbergii) seedlings and dehydrogenase and phosphatase activity of ectomycorrhizal root tips inoculated with seven individual ectomycorrhizal fungal species at high and low nitrogen conditions. Soil Biology and Biochemistry, 40, 1235-1243. http://dx.doi.org/10.1016/j.soilbio.2007.12.017

Tibbett, M., Chambers, S. M., \& Cairney, J. W. G. (1998). Methods for determinating extracellular and surface-bound phosphatase activities in ectomycorrhizal fungi. In A. Varma (Ed.), Mycorrhiza Manual (pp. 217-226). Springer, New York. http://dx.doi.org/10.1111/j.1469-8137.2005.01401.x

Tran, H. T., Hurley, B. A., \& Plaxton, W. C. (2010). Feeding hungry plants: The role of purple acid phosphatases in phosphate nutrition. Plant Science, 179, 14-27. http://dx.doi.org/10.1016/j.plantsci.2010.04.005

van Aarle, I. M., \& Plassard, C. (2010). Spatial distribution of phosphatase activity associated with ectomycorrhizal plants is related to soil type. Soil Biology \& Biochemistry, 42, 324-330. http://dx.doi.org/10.1016/j.soilbio.2009.11.011

Wang, F. Y., Lin, X. G., Yin, R., \& Wu, L. H. (2006). Effects of arbuscular mycorrhizal inoculation on the growth of Elsholtzia splendens and Zea mays and the activities of phosphatase and urease in a multi-metal-contaminated soil under unsterilized conditions. Applied Soil Ecology, 31, 110-119. http://dx.doi.org/10.1016/j.apsoil.2005.03.002

Wasaki, J., Maruyama, H., Tanaka, M., Yamamura, T., Dateki, H., Shinano, T., \& Osaki, M. (2009). Over 
expression of the LASAP2 gene for secretory acid phosphatase in white lupin improves the phosphorus uptake and growth of tobacco plants. Soil Science \& Plant Nutrition, 55, 107-113. http://dx.doi.org/10.1111/j.1747-0765.2008.00329.x

Wu, Q. S., Zou, Y. N., \& He, X. H. (2011). Differences of hyphal and soil phosphatase activities in drought-stressed mycorrhizal trifoliate orange (Poncirus trifoliata) seedlings. Scientia Horticulturae, 129, 294-298. http://dx.doi.org/10.1016/j.scienta.2011.03.051

Zhang, Q., Wang, C., Tian, J., Li, K., \& Shou, H. (2011). Identification of rice purple acid phosphatases related $\begin{array}{llllll}\text { to } & \text { posphate starvation } & \text { signaling. }\end{array}$ http://dx.doi.org/10.1111/j.1438-8677.2010.00346.x

\section{Copyrights}

Copyright for this article is retained by the author(s), with first publication rights granted to the journal.

This is an open-access article distributed under the terms and conditions of the Creative Commons Attribution license (http://creativecommons.org/licenses/by/3.0/). 